JURNAL NUANSA INFORMATIKA

Volume 13 Nomor 2, Juli 2019
p-ISSN : 1858-3911, e-ISSN : 2614-5405

https://journal.uniku.ac.id/index.php/ilkom

\title{
GAME EDUKASI WORD SEARCH PUZZLE NAMA ANAK HEWAN DALAM BAHASA SUNDA MENGGUNAKAN ALGORITMA LINEAR CONGRUENT METHOD (LCM) DAN ALGORITMA KNUTH MORRIS PRATT (KMP) (Studi Kasus : SDN Pajawanlor)
}

\author{
Dessi Hermawaty ${ }^{1}$, Rio Andriyat Krisdiawan ${ }^{2}$, Yati Nurhayati ${ }^{3}$ \\ Fakultas Ilmu Komputer Universitas Kuningan \\ Jalan Tjut Nyak Dhien No. 36 A Cijoho Kuningan Jawa Barat 45513Telepon (0232) 2875097 \\ dessihermawaty@gmail.com ${ }^{1}$, rioandriyat@uniku.ac.id / rioandriyat@gmail.com ${ }^{2}$ \\ yati.nurhayati@uniku.ac.id ${ }^{3}$
}

Bahasa Sunda memiliki penamaan-penamaan yang unik pada ruang lingkup kesehariannya, seperti pada penamaan anak hewan. Mempelajari nama-nama anak hewan menggunakan bahasa Sunda merupakan salah satu kegiatan dalam melestarikan Budaya Sunda. Akan tetapi, khususnya siswa/i sekolah dasar kurang memiliki minat dalam belajar Bahasa Sunda salah satunya mengenai nama-nama anak hewan dalam Bahasa Sunda, hal ini dikarenakan media pembelajaran yang kurang menarik, belum adanya perkembangan dalam pengemasan materi Bahasa Sunda khususnya pengenalan nama-nama anak hewan dan belum adanya kamus mengenai khusus nama-nama anak hewan disekolah tersebut. Oleh karena itu, dibutuhkan sebuah aplikasi menarik untuk membantu pembelajaran Bahasa Sunda agar siswa/i memiliki ketertarikan dalam mempelajari nama-nama anak hewan dalam Bahasa Sunda. Adapun hasil penelitian ini adalah sebuah aplikasi game, dimana didalamnya terdapat materi mengenai nama-nama anak hewan dalam Bahasa Indonesia dan Bahasa Sunda serta terdapat soal yang harus diselesaikan dalam batas waktu tertentu untuk melatih kemampuan Bahasa Sunda dan mengetahui sejauh mana pemahaman Bahasa Sunda siswa/i. Dengan menggunakan algoritma Linear Congruent Method (LCM) untuk mengacak soal yang muncul dalam game dan Knuth Morris Pratt (KMP) untuk pencocokan string dalam game. Adapun aplikasi ini dibangun dengan menggunakan bahasa pemrograman C\# dan tools develop yang digunakan adalah Unity. Dan metode pengembangan sistem pada aplikasi ini menggunakan metode Rational Unified Process (RUP), sedangkan metode untuk perancangan sistem penulis menggunakan Unified Modeling Language (UML).

Kata Kunci : Bahasa Sunda, Linear Congruent Method, Knuth Morris Pratt

Sundanese has unique names in its daily scope, such as naming animals. Learning the names of animal child using Sundanese is one of the activities in preserving Sundanese culture. However, especially elementary school students have lacked interest in learning Sundanese, one of them concerning the names of animal child in Sundanese, this is because the learning medias are less attractive, there are no developments in the packaging of Sundanese materials, especially the introduction to names of animal child and the absence of a dictionary regarding to the names of children in the school. Therefore, an interesting application is needed to help learning Sundanese so that students have an interest in learning the names of animal child in Sundanese. The result of this study is a game application, in which there are material about the names of animal child in Indonesian and Sundanese and there are questions that must be answered in a certain time limit to practice Sundanese language skills and to know the extent to which students understand Sundanese. By using the Linear Congruent Method (LCM) algorithm to scramble the questions that appear in the game and Knuth Morris Pratt (KMP) for matching strings in the game. The application is built using the C\# programming language and the development tools used are Unity. And the system development method in this application uses the Rational Unified Process (RUP) method, while the method for designing the system uses the Unified Modeling Language (UML).

Keywords : Sundanese, Linear Congruent Method, Knuth Morris Pratt 
JURNAL NUANSA INFORMATIKA

Volume 13 Nomor 2, Juli 2019

\section{PENDAhUluAN}

Salah satu genre game yang memiliki content pendidikan lebih dikenal dengan istilah game edukasi. Untuk game word search puzzle (pencarian kata) adalah permainan berbasis puzzle untuk mencari kata-kata yang disusun dalam bentuk matriks. Kata-kata tersebut dapat disusun dari atas ke bawah, bawah ke atas, diagonal, kanan ke kiri atau kiri ke kanan. Penyelesaian dari permainan word search puzzle ini adalah menemukan semua kata yang tersembunyi pada papan permainan yang berbentuk matriks.

Indonesia dikenal memiliki dua bahasa sebagai sarana berkomunikasi yaitu bahasa Indonesia dan bahasa daerah. Adapun salah satu dari bahasa daerah adalah Bahasa Sunda, yang menjadi salah satu identitas suku bangsa sunda yang berasal dari bagian barat pulau Jawa. Bahasa Sunda tidak hanya digunakan sebagai sarana komunikasi saja tetapi bahasa sunda juga merupakan pelajaran muatan lokal di tingkat SD, SMP dan SMA.

SDN Pajawanlor adalah salah satu sekolah dasar yang menerapkan mata pelajaran Bahasa Sunda dari kelas 1 sampai kelas 6. Dimana dalam pelajaran bahasa sunda tersebut mempelajari nama-nama anak hewan dalam Bahasa Sunda yang merupakan salah satu kegiatan dalam melestarikan Budaya Sunda. Akan tetapi, siswa/i masih kurang menghafal dan mengenal namanama anak hewan dalam Bahasa Sunda karena media pembelajaran yang kurang interaktif dan menarik, belum adanya perkembangan dalam pengemasan materi khususnya pengenalan namanama anak hewan dalam Bahasa Sunda dan belum adanya kamu mengenai khusus nama anak hewan disekolah tersebut. Oleh karena itu, permasalahan tersebut didapat sebuah ide untuk membuat sebuah game edukasi yang digunakan untuk membantu para siswa/i dalam mengenalkan kembali namanama anak hewan dalam Bahasa Sunda.

Berdasarkan pemasalahan diatas, maka dalam penelitian ini penulis akan
p-ISSN : 1858-3911, e-ISSN : 2614-5405

https://journal.uniku.ac.id/index.php/ilkom

mengusulkan pembuatan aplikasi game edukasi dengan mengunakan algoritma Linear Congruent Method untuk mengacak soal yang muncul didalam game dan algoritma Knuth Morris Pratt untuk pencocokan string dalam game dengan judul skripsi "Game Edukasi Word Search Puzzle Nama Anak Hewan Dalam Bahasa Sunda Menggunakan Algoritma Linear Congruent Method Dan Algoritma Knuth Morris Pratt (Studi Kasus: SDN Pajawanlor)".

\section{METODE PENELITIAN}

2.1 Metode Pengembangan Sistem

Metode pengembangan sistem yang digunakan dalam penelitian ini adalah dengan metode $R U P$.

Relational Unified Process (RUP) merupakan suatu metode rekayasa perangkat lunak yang dikembangkan dengan mengumpulkan berbagai best practises yang terdapat dalam industri pengembangan perangkat lunak. Ciri utama metode ini adalah menggunakan use-case driven dan pendekatan iteratif untuk siklus pengembangan perangkat lunak.

Ada 4 fase yang akan digunakan adalah sebagai berikut :

1. Inception (permulaan)

Tahapan yang fokus pada penentuan manfaat aplikasi perangkat lunak yang harus dihasilkan. Hasil dari tahap pertama adalah adanya bayangan umum projek yang akan dibuat.

2. Elaboration (Analisis dan Desain)

Ditahap ini akan mulai dilakukan rancang bangun perangkat lunak secara interative melalui aktifitasaktifitas seperti bussiness, modeling, requirements, analysis dan desaign

3. Construction (Koding dan Implementasi)

Tahapan yang berisi pengimplementasi rancangan aplikasi perangkat lunak yang telah dibuat lengkap dan siap diserahkan kepada user.

4. Transition (Testing dan Maintenance) 
JURNAL NUANSA INFORMATIKA

Volume 13 Nomor 2, Juli 2019

Tahapan untuk menyediakan sistem untuk digunakan oleh user. Aktifitas yang dilakukan pada tahap ini yaitu memberikan pelatihan kepada user, pemeliharaan dan pengujian apakah sistem sudah sesuai dengan harapan user.

Berikut adalah gambar dari tahapan RUP :

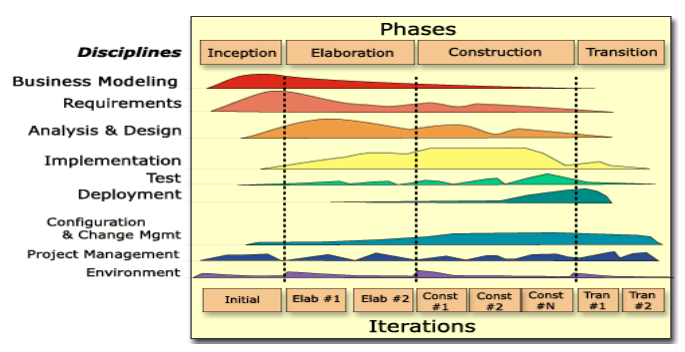

Gambar 1 Tahapan RUP (Sumber: Rio

Andriyat Krisdiawan, 2018)

\subsection{Metode Pemecahan Masalah}

Metode pemecahan masalah yang digunakan dalam penelitian ini adalah dengan menggunakan algoritma Linear Congruent Method dan algoritma Knuth Morris Pratt.

\section{Algoritma Linear Congruent Method}

Linear Congruent Method (LCM) merupakan metode pembangkitkan bilangan acak yang banyak digunakan dalam program komputer. LCM memanfaatkan model linear untuk membangkitkan bilangan acak yang didefinisikan dengan :

\section{$\mathbf{X n}+1=(\mathbf{a X n}+\mathbf{c})(\bmod \mathbf{m})$}

Dimana: $\mathbf{n}$ adalah bilangan acak ke $n$ a dan c adalah konstanta Linear Congruent Method.

m adalah batas maksimum bilangan acak.

Sebagai contoh kasus dalam aplikasi Game Edukasi Word Search Puzzle nama hewan dalam Bahasa Sunda, algoritma LCM akan mengacak urutan soal nama-nama anak hewan dalam Bahasa Sunda yang akan ditampilkan untuk dijawab pada papan kata oleh user. Jika didalam game tedapat dua level dan tiap level memiliki 9 soal maka dengan pengacakan LCM akan
p-ISSN : 1858-3911, e-ISSN : 2614-5405

https://journal.uniku.ac.id/index.php/ilkom

didapat pengacakan susunan sebagai berikut :

Diketahui :

$\mathrm{a}=1, \mathrm{c}=7, \mathrm{~m}=9$ dan $\mathrm{x}(0)=9$, dimana nilai $x(0)$ didapat dari pembangkit bilangan acak $1 \geq \mathrm{n} \leq 9$. Maka :

Rumus :

$$
\mathrm{Xn}+1=(\mathrm{aXn}+\mathrm{c})(\bmod \mathrm{m})
$$

Penyelesaian :

$$
\begin{aligned}
& \mathrm{x}(0)=9 \\
& \mathrm{x}(1)=(1(9)+7) \bmod 9=7 \\
& \mathrm{x}(2)=(1(7)+7) \bmod 9=5 \\
& \mathrm{x}(3)=(1(5)+7) \bmod 9=3 \\
& \mathrm{x}(4)=(1(3)+7) \bmod 9=1 \\
& \mathrm{x}(5)=(1(1)+7) \bmod 9=8 \\
& \mathrm{x}(6)=(1(8)+7) \bmod 9=6 \\
& \mathrm{x}(7)=(1(6)+7) \bmod 9=4 \\
& \mathrm{x}(8)=(1(4)+7) \bmod 9=2
\end{aligned}
$$

Dari pengujian diatas didapat urutan kemunculan untuk 9 soal adalah 9, 7, 5, 3, 1, 8, 6, 4. Urutan tersebut menandakan posisi kemunculan dari urutan gambargambar yang akan ditampilkan didalam game tersebut. Dengan nilai maksimal pengacakan 9 dan dengan nilai konstanta yang sesuai maka dapat terlihat seakan-akan urutan kemunculan tidak terjadi perulangan. Dari hasil pengacakan 9 soal juga tidak ada kemunculan nilai yang sama saat melakukan pengacakan dengan menggunakan algoritma LCM.

\section{Algoritma Knuth Morris Pratt}

adalah salah satu algoritma pencocokan string. Algoritma Knuth Morris Pratt adalah algoritma yang dikembangkan secara terpisah oleh D. E. Knuth pada tahun 1967 dan J. H Morris Bersama V. R Pratt pada tahun 1966, namun keduanya mempublikasikannya secara bersamaan pada tahun 1977. Secara sistematis, langkah-langkah yang harus dilakukan algoritma Knuth Morris Pratt, yaitu :

1. Algoritma Knuth Morris Pratt mulai mencocokan pattern pada awal teks.

2. Dari kiri ke kanan, algoritma ini akan mencocokan karakter perkarakter pattern, dengan karakter diteks yang 
JURNAL NUANSA INFORMATIKA

Volume 13 Nomor 2, Juli 2019

\begin{tabular}{|l|l|l|}
\hline $\mathbf{P}$ & Prefixes & Suffixes \\
\hline E & No prefix & No suffix \\
\hline EN & {$[\mathrm{E}]$} & {$[\mathrm{N}]$} \\
\hline ENE & {$[\mathrm{E}, \mathrm{EN}]$} & {$[\mathrm{E}, \mathrm{NE}]$} \\
\hline ENEN & {$[\mathrm{E}, \mathrm{EN}, \mathrm{ENE}]$} & {$[\mathrm{N}, \mathrm{EN}, \mathrm{NEN}]$} \\
\hline ENENG & {$[\mathrm{E}, \mathrm{EN}, \mathrm{ENE}, \mathrm{ENEN}]$} & {$[\mathrm{G}, \mathrm{NG}, \mathrm{ENG}, \mathrm{NENG}]$} \\
\hline
\end{tabular}

bersesuaian sampai salah satu kondisi berikut terpenuhi :

a. Karakter di pattern dan diteks yang dibandingkan tidak cocok (mismatch).

b. Semua karakter di pattern cocok, kemudian algoritma memberitahukan penemuan diposisi ini.

3. Algoritma kemudian menggeser pattern berdasarkan table next, lalu menghitung langkah 2 sampai pattern berada diujung teks.

Secara sistematis, langkah-langkah yang dilakukan algoritma Knuth Morris Pratt pada saat mencocokan string terdapat 2 tahap yaitu adalah sebagai berikut :

\section{Tahap Preprocessing}

Pada proses awal (preprocessing), algoritma melakukan proses awal (preprocessing) terhadap pattern $\mathrm{P}$ dengan menghitung fungsi pinggiran yang mengindikasikan pergeseran yang mungkin dengan menggunakan perbandingan yang dibentuk sebelum pada tahap pencarian string. Fungsi tersebut akan menghasilkan output berupa array integer yang merupakan angka-angka pinggiran untuk setiap posisi iterasi pada pattern. Sebagai contoh, pada tabel 1 tinjau pattern $\mathrm{P}=$ ENENG. Nilai $b(j)$ untuk setiap karakter di dalam $P$ adalah sebagai berikut :

Tabel 1 Tabel Pattern

\begin{tabular}{|l|l|l|l|l|l|}
\hline $\mathbf{P}$ & $\mathrm{E}$ & $\mathrm{N}$ & $\mathrm{E}$ & $\mathrm{N}$ & $\mathrm{G}$ \\
\hline $\mathbf{P}[\mathbf{j}]$ & 1 & 2 & 3 & 4 & 5 \\
\hline
\end{tabular}

Dari pattern pada tabel 1 kemudian diambil kemungkinan dari substring pattern pada tabel 2 tersebut yaitu :

Tabel 2 Tabel Substring Pattern

\begin{tabular}{|l|l|}
\hline 1 & E \\
\hline 2 & EN \\
\hline 3 & ENE \\
\hline 4 & ENEN \\
\hline 5 & ENENG \\
\hline
\end{tabular}

p-ISSN : 1858-3911, e-ISSN : 2614-5405

https://journal.uniku.ac.id/index.php/ilkom

Kemudian dari setiap substring pattern tersebut diambil semua kemungkinan awalan (prefix) dan akhiran (suffix) pada tabel 3 :

Tabel 3 Kemungkinan Prefix dan Suffix

Setelah diambil dari setiap kemungkinan prefix dan suffix dari substring pattern, maka lihat panjang prefix yang yang sama dengan akhiran suffix pada tabel 4 :

Tabel 4 Tabel Prefix dan Suffix

\begin{tabular}{|l|l|}
\hline E & 0 \\
\hline EN & 0 \\
\hline ENE & $1[$ E] \\
\hline ENEN & $2[$ EN] \\
\hline ENENG & 0 \\
\hline
\end{tabular}

Maka dari setiap kemungkinan tersebut didapatkan hasil pada tabel 5 sebagai berikut :

Tabel 5 Tabel Fungsi Pinggiran

\begin{tabular}{|l|l|l|l|l|l|}
\hline $\boldsymbol{P}$ & $\mathrm{E}$ & $\mathrm{N}$ & $\mathrm{E}$ & $\mathrm{N}$ & $\mathrm{G}$ \\
\hline $\boldsymbol{P}[j]$ & 1 & 2 & 3 & 4 & 5 \\
\hline $\boldsymbol{b}[j]$ & 0 & 0 & 1 & 2 & 0 \\
\hline
\end{tabular}

Keterangan :

$\mathrm{J}=$ Index $\quad \mathrm{P}[\mathrm{j}]=$ Pattern

$B[j]=$ Nilai pinggiran

\section{Tahap Pencarian}

Setelah didapatkan nilai pinggiran dari pattern pada tahap preprocessing tersebut barulah kemudian dapat diproses pencocokan antara pattern dan teks yang diberikan pada tahap kedua yaitu tahap pencarian.

Sebagai contoh diberikan sebuah Teks $=$ HEWENENGAN dan Pattern $=$ ENENG yang sudah diketahui nilai pinggiranya pada tabel 5, setelah didapatkan nilai pinggiran pattern maka proses pencarian string dapat diproses sebagai berikut :

Tabel 6 Tabel pencarian

\begin{tabular}{|l|l|l|l|l|l|l|l|l|l|l|}
\hline Index & 1 & 2 & 3 & 4 & 5 & 6 & 7 & 8 & 9 & 10 \\
\hline Teks & H & E & W & E & N & E & N & G & A & N \\
\hline Pattern & E & N & E & N & G & & & & & \\
\hline B[j] & 0 & 0 & 1 & 2 & 0 & & & & & \\
\hline
\end{tabular}

Berikut tahap proses pencarian string terhadap teks yang sudah diketahui nilai pinggiran dari pattern : 
JURNAL NUANSA INFORMATIKA

Volume 13 Nomor 2, Juli 2019

Tabel 7 Pencarian iterasi ke-1

Pada tabel diatas, pattern E tidak cocok dengan teks $\mathrm{H}$, maka lihat nilai pinggiran pattern $\mathrm{E}$ pada tabel 5 adalah 0 . Karena tidak terjadi ketidakcocokan maka pattern digeser sejumlah 1 karakter ke kanan.

Tabel 8 Pencarian iterasi ke-2

Pada tabel diatas, pattern E cocok dengan teks $\mathrm{E}$, namun pada satu posisi pattern $\mathrm{N}$ terjadi ketidakcocokan dengan teks $\mathrm{W}$ maka lihat nilai pinggiran pattern $\mathrm{E}$ pada tabel 5 adalah 0 . Karena pada pencocokan pattern $\mathrm{N}$ terjadi kecocokan dengan teks E maka pattern digeser sebesar jumlah kecocokan nilai pinggiran yaitu $1-0=1$. Kemudian pattern digeser sejumlah 1 karakter ke kanan.

Tabel 9 Pencarian iterasi ke-3

\begin{tabular}{|c|c|c|c|c|c|c|c|c|c|c|}
\hline Index & 1 & 2 & 3 & 4 & 5 & 6 & 7 & 8 & 9 & 10 \\
\hline Teks & $\mathrm{H}$ & $E$ & W & $E$ & $\mathrm{~N}$ & $\mathrm{E}$ & $\mathrm{N}$ & G & A & $\mathrm{N}$ \\
\hline Pattern & & & $\mathrm{E}$ & $\mathrm{N}$ & $\mathrm{E}$ & $\mathrm{N}$ & G & & & \\
\hline \multicolumn{11}{|l|}{ KET : } \\
\hline \multicolumn{11}{|c|}{ TidakCocok (missmatch) } \\
\hline \multicolumn{11}{|c|}{ Cocok (match) } \\
\hline
\end{tabular}

Pada tabel diatas, pattern E tidak cocok dengan teks $\mathrm{W}$, maka lihat nilai pinggiran pattern $\mathrm{E}$ pada tabel 5 adalah 0 . Karena tidak terjadi ketidakcocokan maka pattern digeser sejumlah 1 karakter ke kanan.

Tabel 10 Pencarian iterasi ke-4

\begin{tabular}{|l|l|l|l|l|l|l|l|l|l|l|}
\hline Index & 1 & 2 & 3 & 4 & 5 & 6 & 7 & 8 & 9 & 10 \\
\hline Teks & H & E & W & E & N & E & N & G & A & N \\
\hline Pattern & & & & E & N & E & N & G & & \\
\hline KET : & \multicolumn{10}{|c|}{} \\
\hline
\end{tabular}

Pada tabel diatas, pattern E cocok dengan teks $\mathrm{E}$ begitupun pattern $\mathrm{N}$ cocok dengan teks $\mathrm{N}$, pattern $\mathrm{E}$ cocok dengan teks $\mathrm{E}$ dan seterusnya. Ternyata dari semua pattern itu cocok dengan teks maka pencarian selesai dilakukan.
p-ISSN : 1858-3911, e-ISSN : 2614-5405

https://journal.uniku.ac.id/index.php/ilkom

\section{HASIL DAN PEMBAHASAN}

\begin{tabular}{|c|c|c|c|c|c|c|c|c|c|c|}
\hline Index & 1 & 2 & 3 & 4 & 5 & 6 & 7 & 8 & 9 & 10 \\
\hline Teks & $\mathrm{H}$ & $\mathrm{E}$ & W & $\mathrm{E}$ & $\mathrm{N}$ & $\mathrm{E}$ & $\mathrm{N}$ & G & A & $\mathrm{N}$ \\
\hline Pattern & $\mathrm{E}$ & $\mathrm{N}$ & $E$ & $\mathrm{~N}$ & $\mathrm{G}$ & & & & & \\
\hline \multicolumn{11}{|l|}{ KET : } \\
\hline \multicolumn{11}{|c|}{\begin{tabular}{l|l} 
& TidakCocok (missmatch) \\
\end{tabular}} \\
\hline \multicolumn{11}{|c|}{ Cocok (match) } \\
\hline Index & 1 & 2 & 3 & 4 & 5 & 6 & 7 & 8 & 9 & 10 \\
\hline Teks & $\mathrm{H}$ & $E$ & W & $\mathrm{E}$ & $\mathrm{N}$ & $\mathrm{E}$ & $\mathrm{N}$ & G & A & $\mathrm{N}$ \\
\hline \multicolumn{2}{|l|}{ Pattern } & $E$ & $\mathrm{~N}$ & $\mathrm{E}$ & $\mathrm{N}$ & G & & & & \\
\hline \multicolumn{7}{|c|}{ KET : } & & & & \\
\hline \multicolumn{7}{|c|}{ TidakCocok (missmatch) } & & & & \\
\hline \multicolumn{7}{|c|}{ Cocok (match) } & & & & \\
\hline
\end{tabular}

\subsection{Analisis Sistem}

Game Edukasi Word Search Puzzle nama hewan dalam Bahasa Sunda ini merupakan game yang dijadikan salah satu pembelajaran untuk para siswa/i dalam proses mengenalkan nama-nama anak hewan dalam Bahasa Sunda. Dimana dalam game ini terdapat konten untuk pengenalan kata dengan Bahasa Sunda. Dengan adanya media baru untuk belajar mengenal nama-nama anak hewan ini diharapkan siswa/i dapat meningkatkan minat untuk memahami, menghafal, mengenal nama-nama anak hewan dalam Bahasa Sunda dan dengan mempelajari nama-nama anak hewan menggunakan Bahasa Sunda juga merupakan salah satu kegiatan dalam melestarikan Budaya Sunda.

\subsection{Analisis Perangkat Keras}

Berikut ini merupakan komponen perangkat keras yang digunakan oleh penulis untuk membantu penulis dalam membangun sistem yang akan dikembangkan adalah sebagai berikut :

1. Prosesor yang digunakan Core i32348

2. Harddisk $500 \mathrm{~GB}$

3. RAM 4GB

\subsection{Analisisi Perangkat Lunak}

Kebutuhan perangkat lunak merupakan komponen-komponen pendukung untuk dapat menjalankan aplikasi dalam sebuah sistem operasi, adapun sistem operasi yang digunakan 
JURNAL NUANSA INFORMATIKA

Volume 13 Nomor 2, Juli 2019

oleh penulis untuk membangun game ini adalah sebagai berikut :

1. Sistem Operasi Windows 7

2. Rational Rose

3. Unity

4. MySql

Adapun perangkat lunak yang dibutuhkan adalah sebagai berikut :

1. Sistem Operasi Android versi 4.1 (Jelly Bean) atau diatasnya.

\subsection{Usecase Diagram}

Usecase diagram menggambarkan fungsi yang dapat dilakukan oleh sistem Antara player dengan sistem aplikasi, berikut usecase diagram yang di gambarkan :

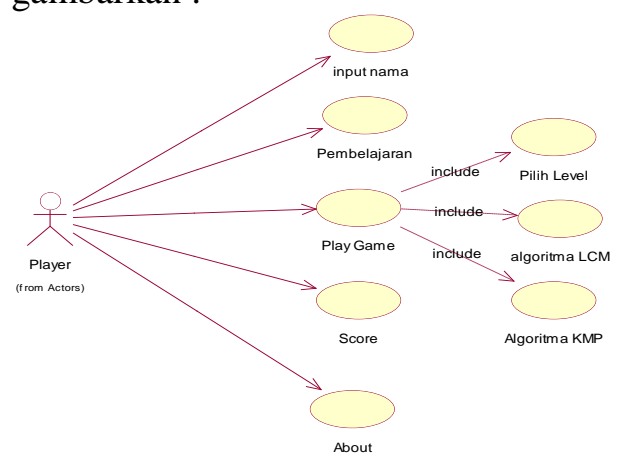

Gambar 2 Use case diagram system

\subsection{Activity Diagram}

3.5.1 Activity Diagram Input Nama

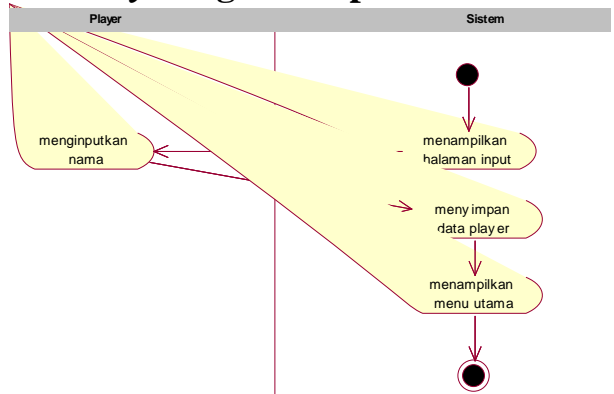

Gambar 3 Activity Diagram Input Nama

\subsubsection{Activity Diagram Pembelajaran}

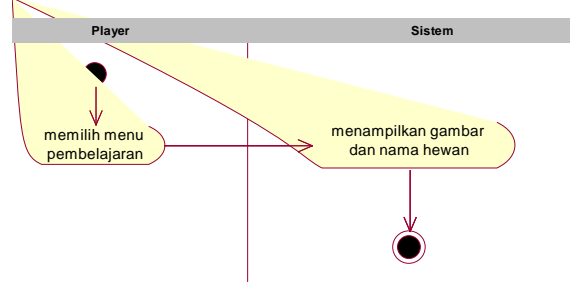

Gambar 4 Activity Diagram Edukasi
p-ISSN : 1858-3911, e-ISSN : 2614-5405

https://journal.uniku.ac.id/index.php/ilkom

\subsubsection{Activity Diagram Play Game}

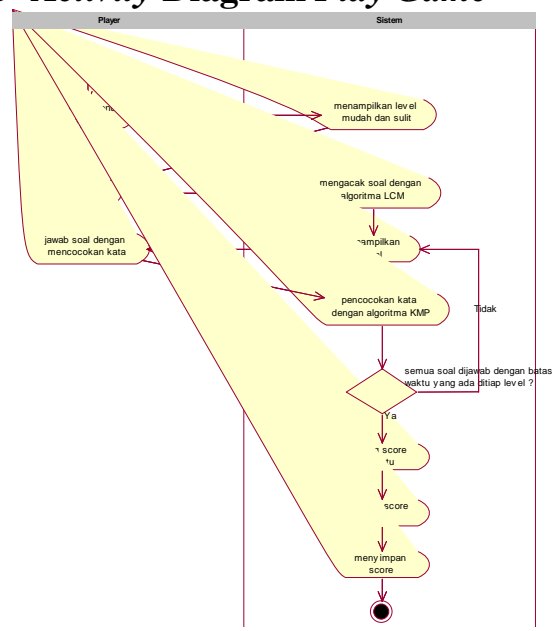

Gambar 5 Activity Diagram PlayGame

\subsubsection{Activity Diagram Score}

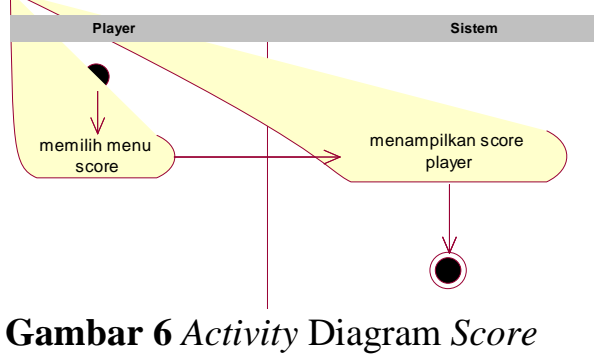

\subsubsection{Activity Diagram About}

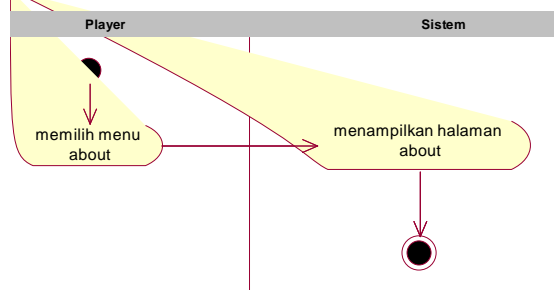

Gambar 7 Activity Diagram About

\subsection{Class Diagram}

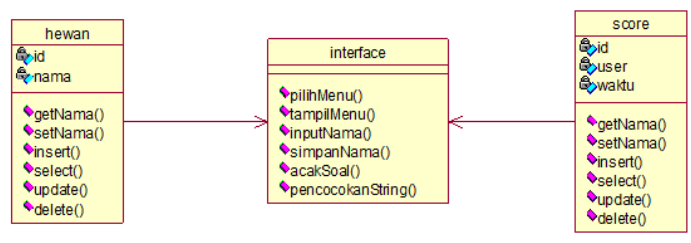

Gambar 8 Class Diagram 
JURNAL NUANSA INFORMATIKA

Volume 13 Nomor 2, Juli 2019

\section{IMPLEMENTASI SISTEM}

4.1 Tampilan Halaman Input Nama

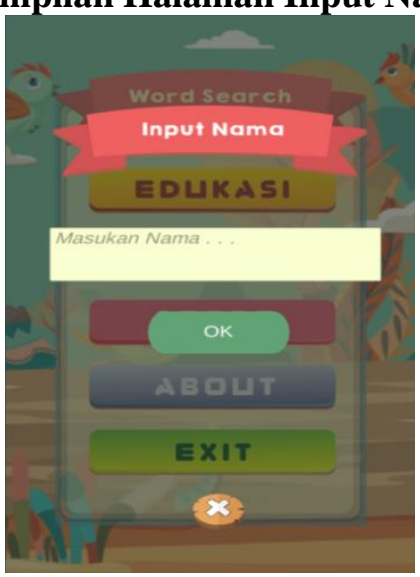

Gambar 9 Tampilan Halaman Input Nama

\subsection{Tampilan Menu Utama}

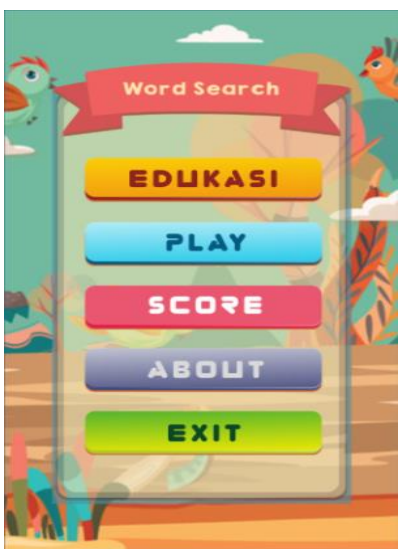

Gambar 10 Tampilan Menu Utama

\subsection{Tampilan Menu Edukasi}

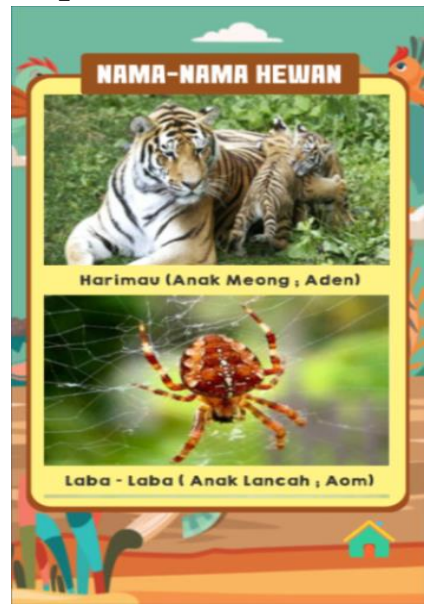

Gambar 11 Tampilan Menu Edukasi
p-ISSN : 1858-3911, e-ISSN : 2614-5405

https://journal.uniku.ac.id/index.php/ilkom

\subsection{Tampilan Menu Level}

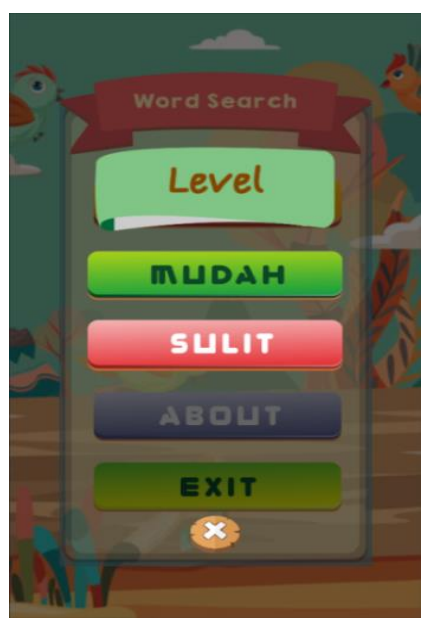

Gambar 12 Tampilan Menu Level

\subsection{Tampilan Play Game}

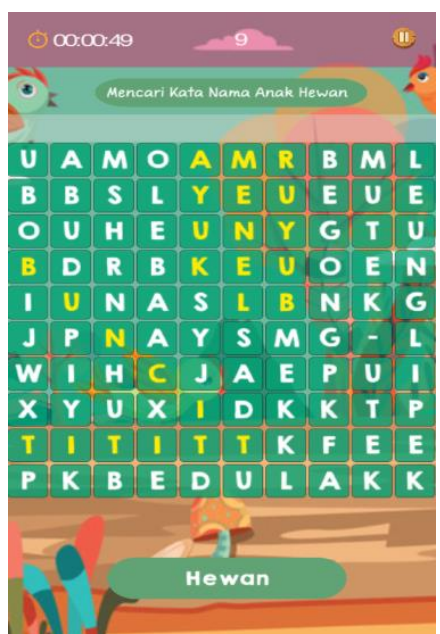

Gambar 13 Tampilan Play Game

\subsection{Tampilan Menu Score}

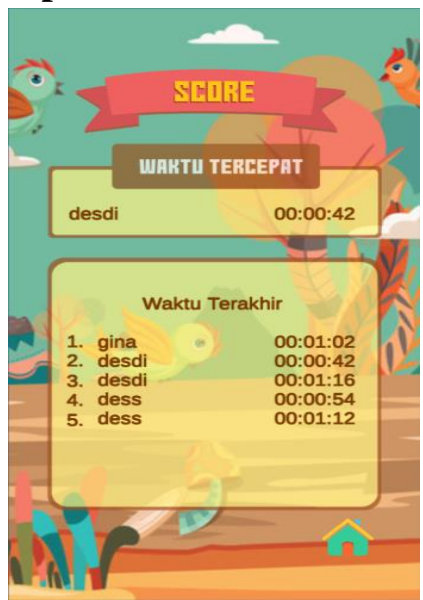

Gambar 14 Tampilan Menu Score 


\subsection{Tampilan Menu About}

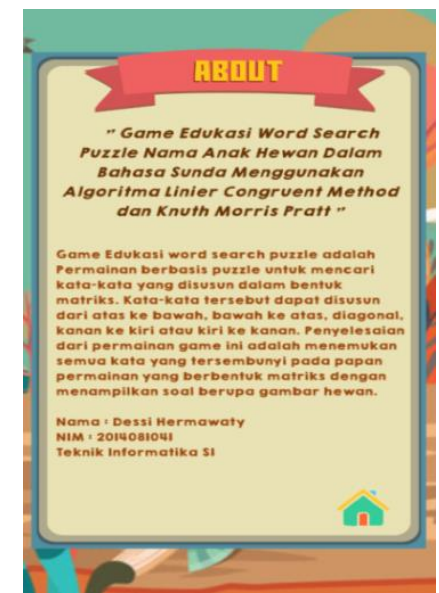

Gambar 15 Tampilan Menu About

\subsection{Tampilan Menu Exit}

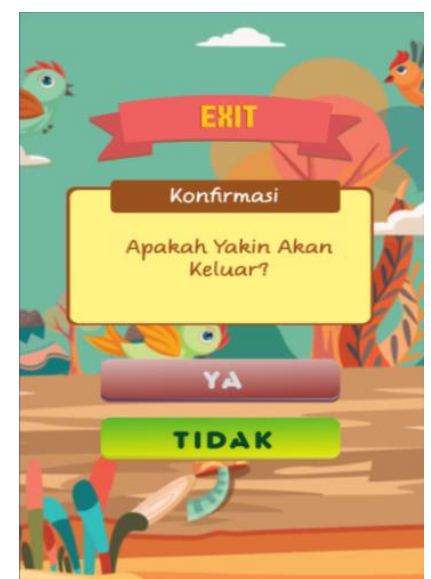

Gambar 16 Tampilan Menu Exit

\section{KESIMPULAN DAN SARAN}

\subsection{Kesimpulan}

Kesimpulan yang dapat diperoleh dari hasil penelitian skripsi "Game Edukasi Word Search Puzzle Nama Hewan Dalam Bahasa Sunda Menggunakan Algoritma Knuth Morris Pratt dan Linear Congruent Method" adalah sebagai berikut :

1. Dengan adanya Game Edukasi Word Search Puzzle, peneliti berupaya memperkenalkan kembali nama-nama anak hewan dengan lebih menarik dalam bentuk game.

2. Game Edukasi Word Search Puzzle dapat menerapkan algoritma Linear Congruent Method untuk pengacakan soal yang ada di dalam papan kata dan algoritma Knuth
p-ISSN : 1858-3911, e-ISSN : 2614-5405

https://journal.uniku.ac.id/index.php/ilkom

Morris Pratt untuk pencocokan string.

\subsection{Saran}

Berdasarkan hasil penelitian yang telah dilakukan, maka penulis merekomendasikan beberapa saran untuk diterapkan pada penelitian selanjutnya. Adapun saran-saran dari penulis :

1. Diharapkan lebih banyak namanama anak hewan dalam Bahasa Sunda didalam Game Edukasi Word Search Puzzle.

2. Diharapkan untuk adanya pengembangan terhadap tampilan aplikasi dan penambahan audio sehingga menjadi lebik menarik.

3. Belum adanya algoritma untuk penyebaran dipapan kata dalam Game Edukasi Word Search Puzzle.

\section{DAFTAR PUSTAKA}

[1] Abdul Kadir. (2013). Pengenalan Algoritma Pendekatan Secara Visual dan Interaktif Menggunakan RAPTOR. Yogyakarta: Andi Offset.

[2] Anhar, ST. (2010). Panduan Menguasai PHP \& MySQL secara Otodidak. Jakarta: Mediakita.

[3] Asep Rojali. (2014). Analisis Perbandingan Algoritma Knuth Morris Pratt Dengan Algoritma Boyer-Moore Pada Permainan Word Search Puzzle. Universitas Komputer Indonesia : Bandung.

[4] Darmawan H., Erico \& Risal, Laurentius, (2011). Pemrograman Berbasis Objek C\# yang Susah Jadi Mudah. Bandung: Informatika.

[5] Eka Agustina Agnia. (2017). Implementasi Algoritma Knuth Morris Pratt Pada Kuis Tebak Nama-Nama Hewan Dalam Aplikasi Pengenalan Hewan. Universitas Kuningan : Kuningan.

[6] Hasibuan, D. P. (2013). Perancangan Simulasi Pengacakan Soal TRYOUT Untuk Membentuk Paket Soal Ujian Nasional Menggunakan Linear Congruent 
JURNAL NUANSA INFORMATIKA

Volume 13 Nomor 2, Juli 2019
p-ISSN : 1858-3911, e-ISSN : 2614-5405

https://journal.uniku.ac.id/index.php/ilkom

$\operatorname{Method}(L C M) . \quad$ STMIK Budi

Darma : Medan.

[7] Krisdiawan, R. A., \& Ramdhany, T. (2018). IMPLEMENTASI ALGORITMA FISHER YATES PADA GAMES EDUKASI PENGENALAN HEWAN UNTUK ANAK SD BERBASIS MOBILE ANDROID. Jurnal Komputer Bisnis, 11(2), 14-22.

[8] Wicaksono, et al. (2013). Penerapan Algoritma Linear Congruent Method Untuk Pengacakan Soal Pada Pengenalan Kampus Berbasis Virtual Reality. STMIK GI MDP : Palembang. 